\title{
Antiproliferative Activity of Acerogenin C, a Macrocyclicdiarylheptanoid, on PDGF-Induced Human Aortic Smooth Muscle Cells Proliferation
}

\author{
Byung-Yoon Cha1, Wen Lei Shi' ${ }^{2}$, Kotaro Watanabe ${ }^{3}$, Takayuki Yonezawa1, \\ Toshiaki Teruya ${ }^{1}$, Kiyotake Suenaga ${ }^{3}$, Yuichi Ishikawa ${ }^{3}$, Shigeru Nishiyama ${ }^{3}$, \\ Kazuo Nagai ${ }^{1,2}$, Je-Tae Woo ${ }^{1,2}$ \\ ${ }^{1}$ Research Institute for Biological Functions, Chubu University, Matsumoto, Japan \\ ${ }^{2}$ Department of Biological Chemistry, Chubu University, Matsumoto, Japan \\ ${ }^{3}$ Department of Chemistry, Faculty of Science and Technology, Keio University, Yokohama, Japan \\ Email: bycha@isc.chubu.ac.jp
}

Received 22 September 2014; accepted 6 February 2015; published 10 February 2015

Copyright (C) 2015 by authors and Scientific Research Publishing Inc.

This work is licensed under the Creative Commons Attribution International License (CC BY).

http://creativecommons.org/licenses/by/4.0/

(c) (i) Open Access

\begin{abstract}
Platelet-derived growth factor (PDGF)-BB is one of the most potent factors in the development and progression of various vascular disorders, such as atherosclerosis and restenosis. PDGF is a major stimulant for vascular smooth muscle cells (VSMCs) proliferation via the mitogenesis signaling pathway. In the present study, we investigated the effect of acerogenin $\mathrm{C}$, a macrocyclicdiarylheptanoid, on PDGF-BB-stimulated human aortic smooth muscle cells (HASMCs) proliferation. Acerogenin C significantly inhibited PDGF $(20 \mathrm{ng} / \mathrm{mL})$-BB-induced $\left[{ }^{3} \mathrm{H}\right]$-thymidine incorporation into DNA at concentrations of $0.1,1$ and $10 \mu \mathrm{M}$ without any cytotoxicity. Acerogenin $C$ also blocked PDGF-BB-stimulated phosphorylation of PLC $\gamma 1$ and Akt but had no effect on extracellular signalregulated kinase 1/2 (ERK1/2) and PDGF beta-receptor $(\mathrm{R} \beta)$ activation. In addition, acerogenin $C$ $(0.1-10 \mu \mathrm{M})$ induced cell-cycle arrest in the $G_{1}$ phase, which was associated with the down-regulation of cyclins and the up-regulation of p27kip1. These results suggest that acerogenin $C$ blocks PDGF-BB-stimulated HASMCs proliferation via $G_{0} / G_{1}$ arrest in association with the induction of p27kip1 and the suppression of PLC $\gamma 1$ and phosphatidylinositol 3-kinase (PI3-K)/Akt signaling pathways. Furthermore, acerogenin $\mathrm{C}$ may be used for prevention and treatment of atherosclerosis during restenosis after coronary angioplasty.
\end{abstract}

\section{Keywords}

HASMCs, Acerogenin C, PDGF-BB, p27 kip1, Cell Cycle

How to cite this paper: Cha, B.-Y., Shi, W.L., Watanabe, K., Yonezawa, T., Teruya, T., Suenaga, K., Ishikawa, Y., Nishiyama, S., Nagai, K. and Woo, J.-T. (2015) Antiproliferative Activity of Acerogenin C, a Macrocyclicdiarylheptanoid, on PDGF-Induced Human Aortic Smooth Muscle Cells Proliferation. Pharmacology \& Pharmacy, 6, 47-55. 


\section{Introduction}

Whereas PDGF is expressed at low levels in arteries in healthy adults, its expression is increased in conjunction with the inflammatory-fibroproliferative response that characterizes atherosclerosis [1]. Thus, studies of balloon catheter-injured arterial tissue [2]-[4], naturally occurring atherosclerosis [5]-[8], coronary arteries after percutaneous transluminal coronary angioplasty [9], and experimentally induced atherosclerosis [10] [11] revealed increased expression of PDGF and PDGF receptors in these lesions.

It is well-known that binding of signal transduction molecules to different phosphorylated tyrosine residues in PDGF-R $\beta$ and PDGF-BB triggers the PI3-K/PKB (Akt) and PLC $\gamma 1$ pathways in addition to the ERK pathway [12]. PI3-K mediates many different cellular responses, including actin reorganization, chemotaxis, cell growth and the serine/threonine kinase Akt/PKB for the antiapoptotic effect [13]-[15]. Interestingly, full activation of PLC $\gamma$ is dependent on PI3-K; the PI(3,4,5)P3 formed by PI3-K binds the PH domain of PLC $\gamma$ and may anchor the enzyme at the membrane [16]. Mitogenic growth factors such as PDGF-BB share a final common signaling pathway in the cell cycle. Quiescent $\left(G_{0}\right)$ cells enter a gap period $\left(G_{1}\right)$, during which the factors necessary for DNA replication in the subsequent synthetic $(S)$ phase are assembled. After DNA replication is completed, the cells enter another gap phase $\left(G_{2}\right)$ in preparation for mitosis (M). Restriction points at the $G_{1}-S$ and $G_{2}-M$ interphases ensure orderly cell cycle progression [17].

In the arterial media, VSMCs are normally quiescent, proliferate at low indices $(<0.05 \%)$, and remain in the $\mathrm{G}_{0} / \mathrm{G}_{1}$ phases of the cell cycle [18]. After vessel injury, vascular smooth muscle cells migrate into the intimal layer of the arterial wall, where they leave their quiescent state and reenter the cell cycle [1]. In many cells, transit through $\mathrm{G}_{1}$ of the cell cycle and entry into the $\mathrm{S}$ phase require the binding and activation of cyclin/CDK complexes, predominantly cyclin D1/CDK4 and cyclin E/CDK2 [19] [20]. The kinase activities of the cyclin/CDK complexes are negatively regulated by CDK inhibitors, such as p27 ${ }^{\text {kip }}{ }^{\text {[21] [22]. }}$

Acerogenin is a diarylheptanoid whose characteristic structural feature is the presence of two hydroxylated aromatic rings tethered by a linear seven-carbon chain. Acerogenin C (Figure 1) was isolated from stems of Boswellia ovalifoliolata BAL. \& HENRY (Burseraceae) [23], while acerogenin C has been synthesized by Gonzalez G. I. et al. [24]. This diarylheptanoid exhibits a broad range of potent biological activities that include anti-inflammatory, antihepatotoxic, antifungal, antibacterial and related effects [23] [25].

However, the mechanism by which acerogenin C affects VSMCs function is still largely unknown. The present study aimed to investigate, for the first time, the inhibitory effects of acerogenin C on PDGF-induced proliferation and signaling transduction pathways in HASMCs.

\section{Materials and Methods}

\subsection{Materials and Reagents}

PDGF-R $\beta$, Akt, PLC $\gamma 1$, ERK1/2, cyclin D1, CDK4, cyclin E, CDK2, p2 $7^{\mathrm{kip} 1}$ and $\alpha$-actin antibodies were purchased from Cell Signaling Technology Inc. (Beverly, MA, USA). Acerogenin C was a gift of Dr. Nishiyama (Department of Chemistry, Faculty of Science and Technology, Keio University; 3-14-1 Hiyoshi, Kohoku-ku, Yokohama 223-8522, Japan).

\subsection{Cell Cultures}

HASMCs were purchased from Cascade Biologics, Inc. (Portland, OR, USA). HASMCs were grown in Dulbecco's Modified Eagle Medium (DMEM) supplemented with 10\% FBS, $100 \mathrm{IU} / \mathrm{mL}$ penicillin and $100 \mu \mathrm{g} / \mathrm{mL}$

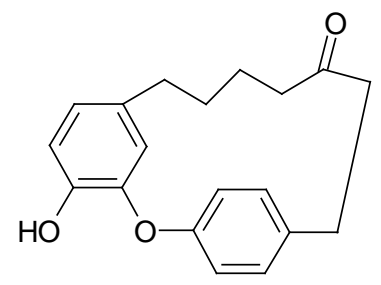

Figure 1. Chemical structures of acerogenin $\mathrm{C}$. 
streptomycin at $37^{\circ} \mathrm{C}$ in a humidified $95 \%$ air $/ 5 \% \mathrm{CO}_{2}$ atmosphere. Cells were used at passages three through eight. For all experiments, HASMCs were grown to $80 \%$ - 90\% confluence and quiescence was induced by starvation for at least $24 \mathrm{~h}$.

\section{3. $\left[{ }^{3} \mathrm{H}\right]$-Thymidine Incorporation Assay}

HASMCs proliferation was determined by $\left[{ }^{3} \mathrm{H}\right]$-thymidine incorporation. HASMCs were incubated for $20 \mathrm{~h}$ with or without PDGF-BB (20 ng/mL) and various concentrations of acerogenins and then pulse-labeled with 1 $\mu \mathrm{Ci} / \mathrm{mL}$ of $\left[{ }^{3} \mathrm{H}\right]$-thymidine for $4 \mathrm{~h}$. Cells were harvested using a Universal Harvester (Perkin Elmer, Waltham, MA, USA) and then transferred to a GF/C filter (Perkin Elmer). The filter was dried and counted in scintillation fluid using a Microplate Scintillation and Luminescence Counter (Topcount NXT, Perkin Elmer).

\subsection{Cell Viability}

Cell viability was determined using the trypan blue dye exclusion method. Cells were incubated for $24 \mathrm{~h}$ with or without PDGF-BB $(20 \mathrm{ng} / \mathrm{mL})$ and various concentrations of acerogenin $\mathrm{C}$ and were then harvested from the dishes using a $0.1 \% \mathrm{w} / \mathrm{v}$ trypsin solution. Cell viability was examined by the trypan blue dye exclusion test. The number of viable cells was estimated by microscopic cell counting using a hemocytometer.

\subsection{SDS-PAGE and Immunoblotting}

Western blotting for protein analysis was performed as described previously [26]. Cells were harvested in lysis buffer containing $1 \mu \mathrm{M}$ sodium vanadate, $1 \mu \mathrm{M}$ phenylmethylsulfonyl fluoride, $5 \mu \mathrm{g} / \mathrm{mL}$ aprotinin and $5 \mu \mathrm{g} / \mathrm{mL}$ leupeptin. The protein concentration was determined by the Bradford assay (Bio-Rad, Hercules, CA, USA). Lysates corresponding to equal amounts of proteins were boiled in Laemmli sample buffer and the supernatants were loaded onto gels for SDS-PAGE. Proteins were transferred onto PVDF membranes and probed with the following primary antibodies: anti-phospho-PDGF-R $\beta$, anti-PDGF-R $\beta$, anti-phospho-PLC $\gamma 1$ (Tyr783), antiPLC $\gamma 1$ anti-phospho-ERK1/2, anti-ERK, anti-phospho-Akt (Thr308) and anti-Akt. Appropriate horseradish peroxidase-coupled secondary antibodies were used at 1:10,000. Immunoreactive bands were visualized using enhanced chemiluminescence (ECL; Amersham Pharmacia Biotech, UK). The detected proteins were normalized to $\alpha$-actin or the respective total protein, as appropriate. The intensities of bands were quantified using SiconImage for Windows (Scion Corporation, Frederick, MA, USA).

\subsection{Cell Cycle Analysis}

HASMCs were seeded in 6-well culture plates and grown in DMEM medium with growth supplement at $37^{\circ} \mathrm{C}$ in a humidified $95 \%$ air $/ 5 \% \mathrm{CO}_{2}$ atmosphere. Cells were grown to $80 \%$ confluence and made quiescent by starvation for at least $24 \mathrm{~h}$. Cells were incubated for $24 \mathrm{~h}$ with or without PDGF-BB $(20 \mathrm{ng} / \mathrm{mL})$ and various concentrations of acerogenin C. Cells were harvested, fixed in $70 \%$ ethanol for $12 \mathrm{~h}$, and stored at $-20^{\circ} \mathrm{C}$. Cells were then washed twice with ice-cold PBS and incubated with $100 \mu \mathrm{g} / \mathrm{mL}$ RNase and $50 \mu \mathrm{g} / \mathrm{mL}$ propidium iodide and cell-cycle phase analysis was performed by flow cytometry using a Cytomics FC500 and CXP Software Ver. 2 software (Beckman Coulter, JAPAN).

\subsection{Statistical Analysis}

Experimental results are expressed as means \pm S.E.M. One-way analysis of variance (ANOVA), followed by Dunnett's test, was used for multiple comparisons. P values of $<0.05$ and $<0.01$ were considered statistically significant.

\section{Results}

\subsection{Effect of Acerogenins on PDGF-Induced HASMCs Proliferation and DNA Synthesis}

In the $\left[{ }^{3} \mathrm{H}\right]$-thymidine incorporation assay (Figure 2(a)), stimulation with PDGF-BB $(20 \mathrm{ng} / \mathrm{mL})$ increased cell proliferation by about 10 -fold. Acerogenin C $(0.1$ to $10 \mu \mathrm{M})$ inhibited PDGF-induced cell proliferation in a concentration-dependent manner with about $90 \%$ inhibition observed at $10 \mu \mathrm{M}$. When quiescent cells were 
treated with acerogenin $\mathrm{C}(0.1$ to $10 \mu \mathrm{M})$ for $24 \mathrm{~h}$ in the absence of PDGF-BB, no significant difference was observed in the extent of $\left[{ }^{3} \mathrm{H}\right]$-thymidine incorporation, suggesting that acerogenins are not cytotoxic at the concentrations tested. In particular, the lack of cytotoxicity of acerogenin $\mathrm{C}$ at the concentrations used in these experiments was confirmed by the trypan blue exclusion assay (Figure 2(b)). The number of cells was significantly increased after $20 \mathrm{ng} / \mathrm{mL}$ PDGF-BB stimulation $\left(28.3 \pm 0.3 \times 10^{4}\right.$ cells/well $)$ compared with the nonstimulated group (13.1 $\pm 0.1 \times 10^{4}$ cells/well) and the increased cells were significantly reduced to $21.2 \pm 0.2$, $15.3 \pm 0.3$ and $14.2 \pm 0.2 \times 10^{4}$ cells/well at concentrations of $0.1,1$ and $10 \mu \mathrm{M}$, respectively (Figure 2(b)).

\subsection{Effect of Acerogenin C on PDGF-Induced PDGF-R $\beta$, PCL $\gamma 1$, Akt and ERK 1/2 Activation}

The HASMCs were pre-incubated in the presence or absence of various concentrations of acerogenin $\mathrm{C}$ in a serum-free medium for $24 \mathrm{~h}$ and then stimulated for $10 \mathrm{~min}$ with $20 \mathrm{ng} / \mathrm{mL}$ PDGF-BB. As shown in Figure 3, PDGF-BB markedly increased phosphorylation levels on the PDGF-R $\beta$ but acerogenin C treatment had no significant effect. To determine the effects of acerogenin $C$ on the downstream intracellular signal transduction pathway of PDGF-BB, we determined the phosphorylation of PLC $\gamma 1$, Akt and ERK1/2. PDGF-BB treatment clearly increased phosphorylation levels on the PLC $\gamma 1$, Akt and ERK1/2. Acerogenin C blocked the phosphorylation of PLC $\gamma 1$ and Akt in a concentration-dependent manner but had no effect on ERK 1/2 phosphorylation.

\subsection{Effect of Acerogenin C on Cell Cycle Progression in HASMCs}

Flow cytometric analysis was performed to determine whether acerogenin C-induced cell growth inhibition was due to an arrest in a specific point of the cell cycle. As shown in Figure 4, pre-incubation of HASMCs in a serum-free medium for $24 \mathrm{~h}$ resulted in approximately $91.8 \pm 2.5 \%$ synchronization of the cell cycle in the G0/G1 phase. During cell cycle analysis, stimulation with PDGF-BB $(20 \mathrm{ng} / \mathrm{mL})$ increased the percentage of cells in the $S$ phase from $5.6 \pm 1.3 \%$ to $27.5 \pm 2.1 \%$. Acerogenin C $(0.1$ to $10 \mu \mathrm{M})$ significantly blocked cell cycle progression in a concentration-dependent manner. The percentage of cells in the $\mathrm{S}$ phase was significantly reduced to $12.6 \pm 1.2 \%(\mathrm{P}<0.05, \mathrm{n}=3), 7.4 \pm 1.4 \%(\mathrm{P}<0.05, \mathrm{n}=3)$ and $5.4 \pm 1.4 \%(\mathrm{P}<0.05, \mathrm{n}=3)$ at concentrations of $0.1,1$ and $10 \mu \mathrm{M}$ acerogenin C, respectively (Figure 4). These results suggest that acerogenin $\mathrm{C}$ may act against DNA synthesis in the early events of the cell cycle.

\subsection{Effect of Acerogenin C on Cell Cycle Regulatory Protein Expression}

Using immunoblot analysis, we analyzed the protein expressions of the cyclins and CDKs, which are known to

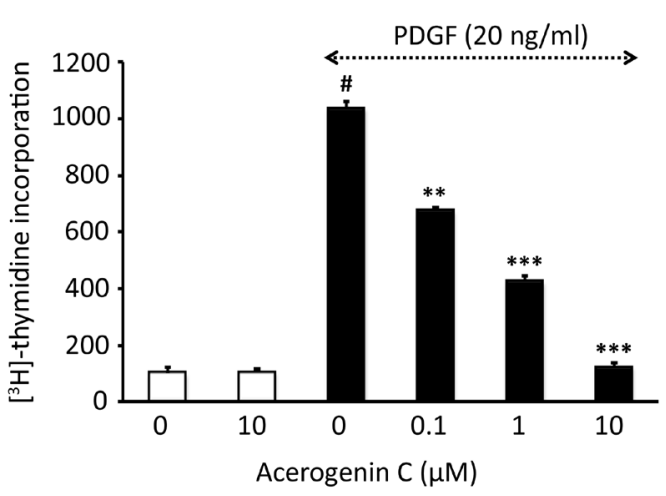

(a)

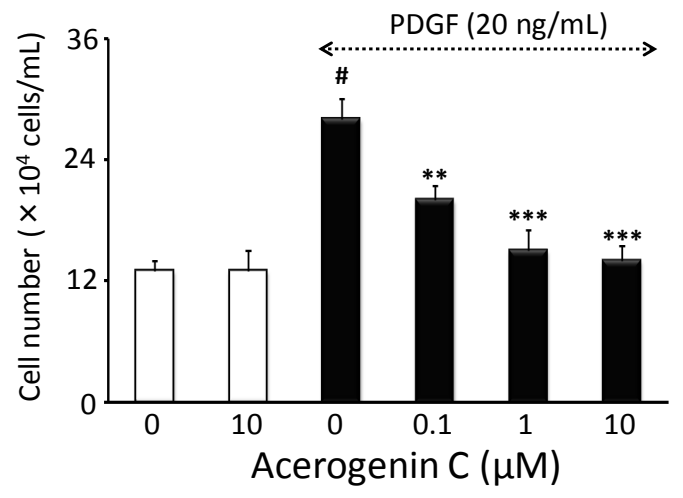

(b)

Figure 2. The effect of acerogenin on PDGF-BB-stimulated HASMCs proliferation. Cells were incubated for $20 \mathrm{~h}$ with or without PDGF-BB (20 ng/mL) and various concentrations of acerogenin C, and then pulse-labeled with [3H]-thymidine for 4 $\mathrm{h}$ (a). The cells were pre-incubated for $24 \mathrm{~h}$ with or without PDGF-BB and indicated concentrations of acerogenin C. The cells were trypsinized and then counted using a hemocytometer (b). Results are means \pm S.E.M. from three independent experiments. $\# \mathrm{P}<0.005$ compared with control; ${ }^{* *} \mathrm{P}<0.01$ and $* * * \mathrm{P}<0.001$ compared with PDGF-stimulation. 


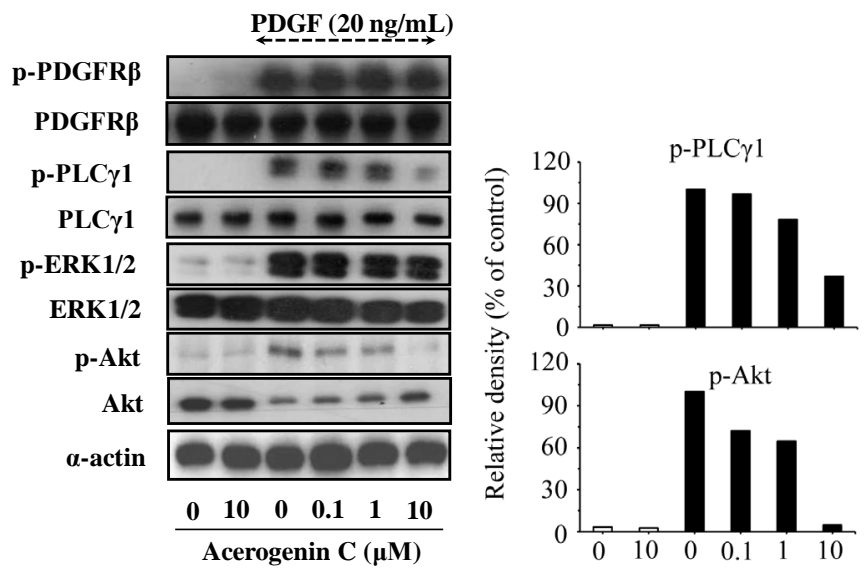

Figure 3. The effect of acerogenin C on PDGF-stimulated PDGF-R $\beta$, ERK 1/2, PLC $\gamma 1$, and Akt phosphorylation in HASMCs. The cells were incubated for $10 \mathrm{~min}$ with or without PDGF-BB and various concentrations of acerogenin $C$ in 6 -well culture plates. Cells were lysed and lysates were immunoblotted with antibodies. Total protein was used for respective normalization. After densitometric quantification, data are representative of at least three independent experiments with similar results.

be regulated by p27 $7^{\text {kip1 }}$, following treatment with acerogenin C. As shown in Figure 5, acerogenin C decreased the protein expression of cyclin E and CDK2, as well as cyclin D1 and CDK4, in a concentration-dependent manner. In addition, the expression of p2 $7^{\text {kip } 1}$, one of the cyclin-dependent kinase inhibitors, was down regulated by PDGF-BB treatment. In contrast, the p $27^{\text {kip } 1}$ protein level was significantly increased by acerogenin $\mathrm{C}$ treatment in a concentration-dependent manner.

\section{Discussion}

In the present study, we found that acerogenin C inhibited DNA synthesis in response to PDGF-BB (Figure 2(a)). As a result, acerogeninC showed a concentration-dependent inhibition of the incorporation of $\left[{ }^{3} \mathrm{H}\right]$-thymidine into HASMCs. Furthermore, the antiproliferative effect of acerogenin C on HASMCs was not due to cellular cytotoxicity, as demonstrated by the cell counting (Figure 2(b)) and MTT assays (data not shown).

To understand the mechanism of down-regulation of PDGF-BB-stimulated HASMCs proliferation, we examined whether the effect of acerogenin $\mathrm{C}$ is mediated by down-regulation of the intracellular signaling pathways.

The PDGF-BB-stimulated mitogenesis signaling pathway has been well characterized. Binding of PDGF-BB to PDGF-R $\beta$ can activate three major signal transduction pathways, PI3-K/Akt, PLC $\gamma 1$ and ERK1/2, by activating Raf-1 [12]. As shown Figure 3, acerogenin C had no effect on the PDGF-BB-induced phosphorylation of PDGF-R $\beta$ at various concentrations. This result suggests that the inhibition of acerogenin $C$ on HASMCs proliferation does not occur at the receptor level. Thus, we did Western blotting to understand the effect of acerogenin C on the downstream signal transduction, such as the PI3-K/Akt, PLC $\gamma 1$ and ERK1/2 signaling pathways. As shown in Figure 3, we observed that acerogenin C specifically inhibited PDGF-stimulated PLC $\gamma 1$ and Akt activation but not PDGFR and ERK1/2 MAP kinase activation in HASMCs. These results are similar to a previous study, in which JM91 inhibited PDGF-induced PI3-K/Akt and ERK1/2 MAP kinase activation but not PDGF R $\beta$ in HASMCs [12]. In the present study, PDGFR $\beta$, PLC $\gamma 1$, ERK1/2 and Akt were used as a control for protein loading. However, the total amount of Akt rapidly decreased upon its activation. PDGF caused a rapid decrease in the Akt protein levels, concomitant with Akt activation. PDGF causes the regulated proteolytic downregulation of Akt, which is dependent on PI3-K and proteasome activities. The proteasome-dependent down- regulation of Akt might be a fundamental mechanism that regulates the activity and function of Akt in VSMCs [27]. Interestingly, full activation of PLC $\gamma$ is dependent on PI3-K; the PI(3,4,5)P3 formed by PI3-K binds the PH domain of PLC $\gamma$ and may anchor the enzyme at the membrane [16]. PLC $\gamma$ appears not to be of primary impor- 


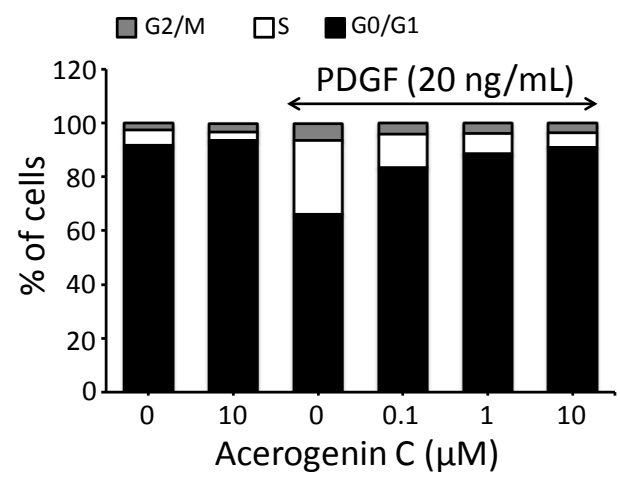

Synchronized cell
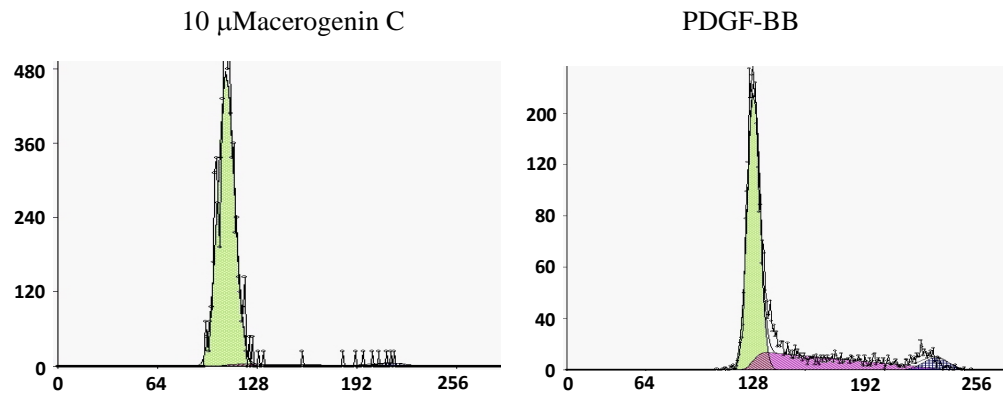

PDGF-BB

$+0.1 \mu$ Macerogenin C
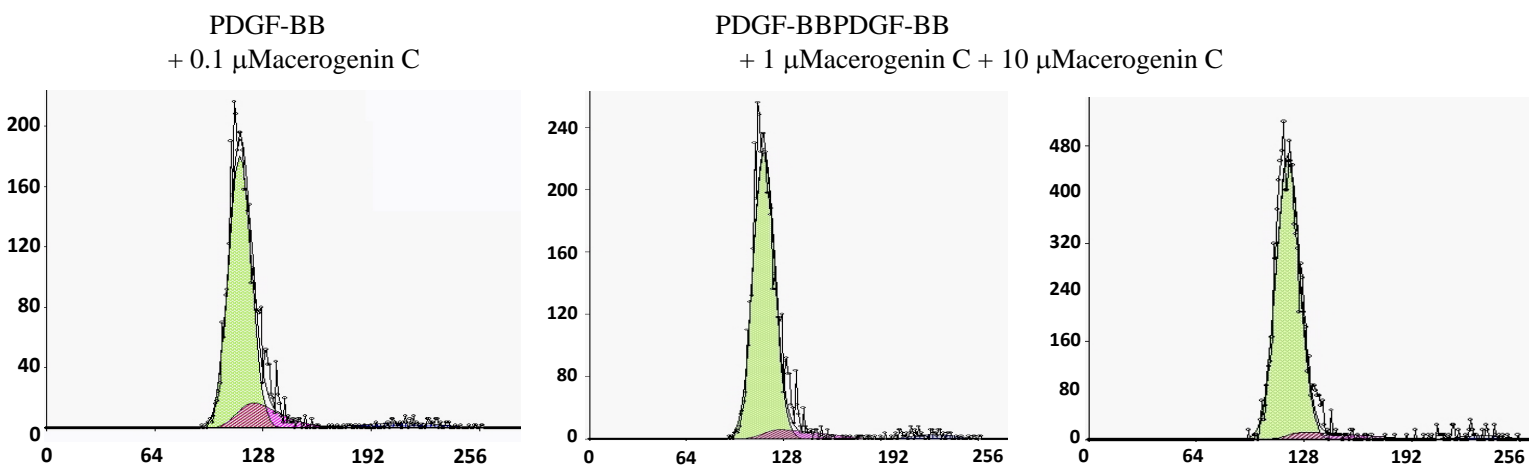

Figure 4. The effect of acerogenin C on PDGF-BB-stimulated cell cycle progression in HASMCs. The cells were incubated for $24 \mathrm{~h}$ with or without PDGF-BB and various concentrations of acerogenin $\mathrm{C}$ in 6 -well culture plates. The cells were trypsinized and then analyzed by flow cytometry. Each item is derived from a representative experiment where data from at least 10,000 events were obtained. Data are representative of at least three independent experiments with similar results.

tance for the stimulation of cell growth and motility in most cell types. However, in certain cell types, PLC $\gamma$ affects these responses [28]. Members of the PI3-K family that bind to and are activated by tyrosine kinase receptors consist of a regulatory subunit, p85, and a catalytic subunit, p110. Their preferred substrate is phosphatidylinositol 4,5-bisphosphate [PI(4,5)P2], which is phosphorylated to phosphatidylinositol 3,4,5-trisphosphate [PI(3,4,5)P3]. Phosphatidylinositol 39-kinase plays a central role in intracellular signal transduction; it can be activated by several different signals, it has a number of downstream effector molecules, and it mediates many different cellular responses, including actin reorganization, chemotaxis, cell growth and antiapoptosis [15].

In addition, cell cycle analysis was performed to investigate the antiproliferative effect of acerogenin $\mathrm{C}$. As shown in Figure 4, acerogenin C inhibits PDGF-BB-stimulated HASMCs proliferation via $G_{0} / G_{1}$ arrest. Several reports suggest that the $G_{1}$ phase is a major point of control for cell proliferation in mammalian cells [29]. Many studies have attributed the regulation of $\mathrm{G}_{1}$ cell-cycle arrest to a number of cellular proteins, including the CDK inhibitor, p2 $7^{\mathrm{kip} 1}$ [22]. Our data demonstrates a significant up-regulation of p2 $7^{\mathrm{kip} 1}$. However, under similar experimental conditions, the expression levels of another cyclin-dependent kinase inhibitor, $\mathrm{p} 21^{\text {waf1 }}$ protein, was not changed (data not shown), suggesting that $\mathrm{p} 21^{\text {waf1 }}$ is unlikely to be involved in the cell-cycle arrest induced 


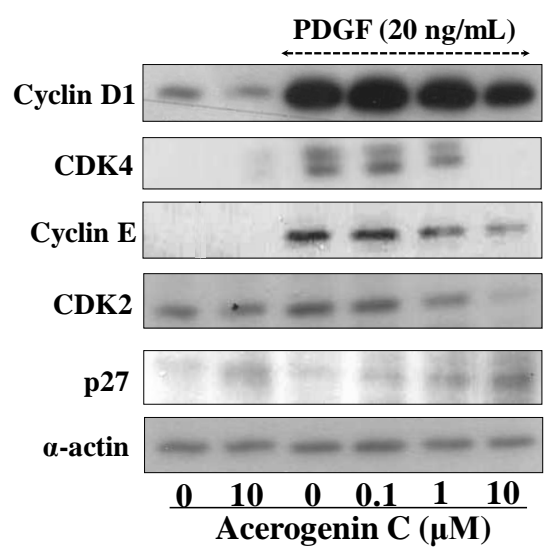

Figure 5. The effect of acerogenin C on PDGF-stimulated expression of cell cycle regulatory proteins in HASMCs. The cells were incubated for $24 \mathrm{~h}$ with or without PDGF-BB and various concentrations of acerogenin $\mathrm{C}$ in 6 -well culture plates. The cells were lysed and proteins were analyzed by SDS-PAGE and immunoblotting. $\alpha$-actin was used for normalization. Data are representative of at least three independent experiments with similar results.

by acerogenin $\mathrm{C}$. We assessed the effect of acerogenin $\mathrm{C}$ treatment on the cyclins and CDKs operative in the $\mathrm{G}_{1}$-phase of the cell cycle, such as cyclin D1, CDK4, cyclin E and CDK2. Acerogenin C inhibited the expression of cyclin D1, CDK4, cyclin E and CDK2 in a concentration-dependent manner. Our results indicate that cell cycle arrest in the $\mathrm{G}_{1}$-phase might be due to the down-regulation of $\mathrm{CDKs} /$ cyclins complex expression.

\section{Conclusion}

We showed that acerogenin C inhibited PDGF-BB-induced HASMCs proliferation via $\mathrm{G}_{0} / \mathrm{G}_{1}$ arrest, in association with the down-regulation of the expression of cyclin D1, CDK4, cyclin E and CDK2 and the up-regulation of $\mathrm{p} 27^{\mathrm{kip} 1}$. Therefore, acerogenin C may be useful for prevention and treatment of vascular diseases, such as restenosis after coronary angioplasty.

\section{Acknowledgements}

This study was performed at a laboratory supported by an endowment from Erina Co., Inc.

\section{References}

[1] Ross, R. (1993) The Pathogenesis of Atherosclerosis: A Perspective for the 1990s. Nature, 362, 801-809. http://dx.doi.org/10.1038/362801a0

[2] Kanzaki, T., Shinomiya, M., Ueda, S., Morisaki, N., Saito, Y. and Yoshida, S. (1994) Enhanced Arterial Intimal Thickening after Balloon Catheter Injury in Diabetic Animals Accompanied by PDGF Beta-Receptor Overexpression of Aortic Media. European Journal of Clinical Investigation, 24, 377-381. http://dx.doi.org/10.1111/j.1365-2362.1994.tb02179.x

[3] Majesky, M.W., Reidy, M.A., Bowen-Pope, D.F., Hart, C.E., Wilcox, J.N. and Schwartz, S.M. (1990) PDGF Ligand and Receptor Gene Expression during Repair of Arterial Injury. Journal of Cell Biology, 111, 2149-2158. http://dx.doi.org/10.1083/jcb.111.5.2149

[4] Uchida, K., Sasahara, M., Morigami, N., Hazama, F. and Kinoshita, M. (1996) Expression of Platelet-Derived Growth Factor B-Chain in Neointimal Smooth Muscle Cells of Balloon Injured Rabbit Femoral Arteries. Atherosclerosis, 124, 9-23. http://dx.doi.org/10.1016/0021-9150(95)05742-0

[5] Libby, P., Salomon, R.N., Payne, D.D., Schoen, F.J. and Pober, J.S. (1989) Functions of Vascular Wall Cells Related to Development of Transplantation-Associated Coronary Arteriosclerosis. Transplantation Proceedings, 21, 36773684.

[6] Libby, P., Warner, S.J., Salomon, R.N. and Birinyi, L.K. (1988) Production of Platelet-Derived Growth Factor-Like Mitogen by Smooth-Muscle Cells from Human Atheroma. New England Journal of Medicine, 318, 1493-1498. 
http://dx.doi.org/10.1056/NEJM198806093182303

[7] Rubin, K., Tingström, A., Hansson, G.K., Larsson, E., Rönnstrand, L., Klareskog, L., et al. (1988) Induction of B-Type Receptors for Platelet-Derived Growth Factor in Vascular Inflammation: Possible Implications for Development of Vascular Proliferative Lesions. Lancet, 1, 1353-1356. http://dx.doi.org/10.1016/S0140-6736(88)92177-0

[8] Wilcox, J.N., Smith, K.M., Williams, L.T., Schwartz, S.M. and Gordon, D. (1988) Platelet-Derived Growth Factor mRNA Detection in Human Atherosclerotic Plaques by in Situ Hybridization. Journal of Clinical Investigation, 82, 1134-1143. http://dx.doi.org/10.1172/JCI113671

[9] Ueda, M., Becker, A.E., Kasayuki, N., Kojima, A., Morita, Y. and Tanaka, S. (1996) In Situ Detection of Platelet-Derived Growth Factor-A and -B Chain mRNA in Human Coronary Arteries after Percutaneous Transluminal Coronary Angioplasty. American Journal of Pathology, 149, 831-843.

[10] Golden, M.A., Au, Y.P., Kirkman, T.R., Wilcox, J.N., Raines, E.W., Ross, R., et al. (1991) Platelet-Derived Growth Factor Activity and mRNA Expression in Healing Vascular Grafts in Baboons. Association in Vivo of Platelet-Derived Growth Factor mRNA and Protein with Cellular Proliferation. Journal of Clinical Investigation, 87, 406-414. http://dx.doi.org/10.1172/JCI115011

[11] Ross, R., Masuda, J., Raines, E.W., Gown, A.M., Katsuda, S., Sasahara, M., et al. (1990) Localization of PDGF-B Protein in Macrophages in All Phases of Atherogenesis. Science, 248, 1009-1012. http://dx.doi.org/10.1126/science.2343305

[12] Seo, J.M., Jin, Y.R., Ryu, C.K., Kim, T.J., Han, X.H., Hong, J.T., et al. (2008) JM91, a Newly Synthesized Indoledione Derivative, Inhibits Rat Aortic Vascular Smooth Muscle Cells Proliferation and Cell Cycle Progression through Inhibition of ERK1/2 and Akt Activations. Biochemical Pharmacology, 75, 1331-1340. http://dx.doi.org/10.1016/j.bcp.2007.11.013

[13] Dudek, H., Datta, S.R., Franke, T.F., Birnbaum, M.J., Yao, R., Cooper, G.M., et al. (1997) Regulation of Neuronal Survival by the Serine-Threonine Protein Kinase Akt. Science, 275, 661-665. http://dx.doi.org/10.1126/science.275.5300.661

[14] Kauffmann-Zeh, A., Rodriguez-Viciana, P., Ulrich, E., Gilbert, C., Coffer, P., Downward, J., et al. (1997) Suppression of c-Myc-Induced Apoptosis by Ras Signalling through PI(3)K and PKB. Nature, 385, 544-548. http://dx.doi.org/10.1038/385544a0

[15] Vanhaesebroeck, B., Leevers, S.J., Panayotou, G. and Waterfield, M.D. (1997) Phosphoinositide 3-Kinases: A Conserved Family of Signal Transducers. Trends in Biochemical Sciences, 22, 267-272. http://dx.doi.org/10.1016/S0968-0004(97)01061-X

[16] Falasca, M., Logan, S.K., Lehto, V.P., Baccante, G., Lemmon, M.A. and Schlessinger, J. (1998) Activation of Phospholipase $\mathrm{C} \gamma$ by PI 3-Kinase-Induced PH Domain-Mediated Membrane Targeting. EMBO Journal, 17, 414-422. http://dx.doi.org/10.1093/emboj/17.2.414

[17] Elledge, S.J. (1996) Cell Cycle Checkpoints: Preventing an Identity Crisis. Science, 274, 1664-1672. http://dx.doi.org/10.1126/science.274.5293.1664

[18] Gordon, D., Reidy, M.A., Benditt, E.P. and Schwartz, S.M. (1990) Cell Proliferation in Human Coronary Arteries. Proceedings of the National Academy of Sciences of the United States of America, 87, 4600-4604. http://dx.doi.org/10.1073/pnas.87.12.4600

[19] Sherr, C.J. (1994) G1 Phase Progression: Cycling on Cue. Cell, 79, 551-555. http://dx.doi.org/10.1016/0092-8674(94)90540-1

[20] Sherr, C.J. (1996) Cancer Cell Cycles. Science, 274, 1672-1677. http://dx.doi.org/10.1126/science.274.5293.1672

[21] Xiong, Y., Hannon, G.J., Zhang, H., Casso, D., Kobayashi, R. and Beach, D. (1993) p21 Is a Universal Inhibitor of Cyclin Kinases. Nature, 366, 701-704. http://dx.doi.org/10.1038/366701a0

[22] Toyoshima, H. and Hunter, T. (1994) p27, a Novel Inhibitor of G1 Cyclin-Cdk Protein Kinase Activity, Is Related to p21. Cell, 78, 67-74. http://dx.doi.org/10.1016/0092-8674(94)90573-8

[23] Akihisa, T., Taguchi, Y., Yasukawa, K., Tokuda, H., Akazawa, H., Suzuki, T., et al. (2006) Acerogenin M, a Cyclic Diarylheptanoid, and Other Phenolic Compounds from Acer nikoense and Their Anti-Inflammatory and Anti-TumorPromoting Effects. Chemical and Pharmaceutical Bulletin, 54, 735-739. http://dx.doi.org/10.1248/cpb.54.735

[24] Gonzalez, G.I. and Zhu, J. (1997) First Total Synthesis of Acerogenin C and Aceroside IV. Journal of Organic Chemistry, 62, 7544-7545. http://dx.doi.org/10.1021/jo9714324

[25] Keseru, G.M. and Nogradi, M. (1995) The Chemistry of Natural Diarylheptanoids. In: Rahman, A.U., Ed., Studies in Natural Products Chemistry, Vol. 17, Elsevier, Amsterdam, 357-394.

[26] Cha, B.Y., Shi, W.L., Yonezawa, T., Teruya, T., Nagai, K. and Woo, J.T. (2009) An Inhibitory Effect of Chrysoeriol on Platelet-Derived Growth Factor (PDGF)-Induced Proliferation and PDGF Receptor Signaling in Human Aortic Smooth Muscle Cells. Journal of Pharmacological Sciences, 110, 105-110. http://dx.doi.org/10.1254/jphs.08282FP 
[27] Adachi, M., Katsumura, K.R., Fujii, K., Kobayashi, S., Aoki, H. and Matsuzaki, M. (2003) Proteasome-Dependent Decrease in Akt by Growth Factors in Vascular Smooth Muscle Cells. FEBS Letters, 554, 77-80. http://dx.doi.org/10.1016/S0014-5793(03)01109-8

[28] Heldin, C.H. and Westermark, B. (1999) Mechanism of Action and in Vivo Role of Platelet-Derived Growth Factor. Physiological Reviews, 79, 1283-1316.

[29] Fang, F. and Newport, J.W. (1991) Evidence That the G1-S and G2-M Transitions Are Controlled by Different cdc2 Proteins in Higher Eukaryotes. Cell, 66, 731-742. http://dx.doi.org/10.1016/0092-8674(91)90117-H 
Scientific Research Publishing (SCIRP) is one of the largest Open Access journal publishers. It is currently publishing more than 200 open access, online, peer-reviewed journals covering a wide range of academic disciplines. SCIRP serves the worldwide academic communities and contributes to the progress and application of science with its publication.

Other selected journals from SCIRP are listed as below. Submit your manuscript to us via either submit@scirp.org or Online Submission Portal.
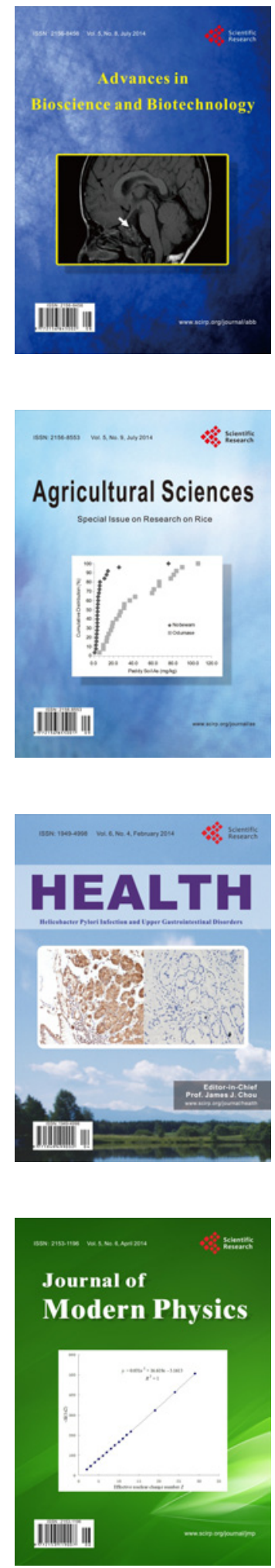
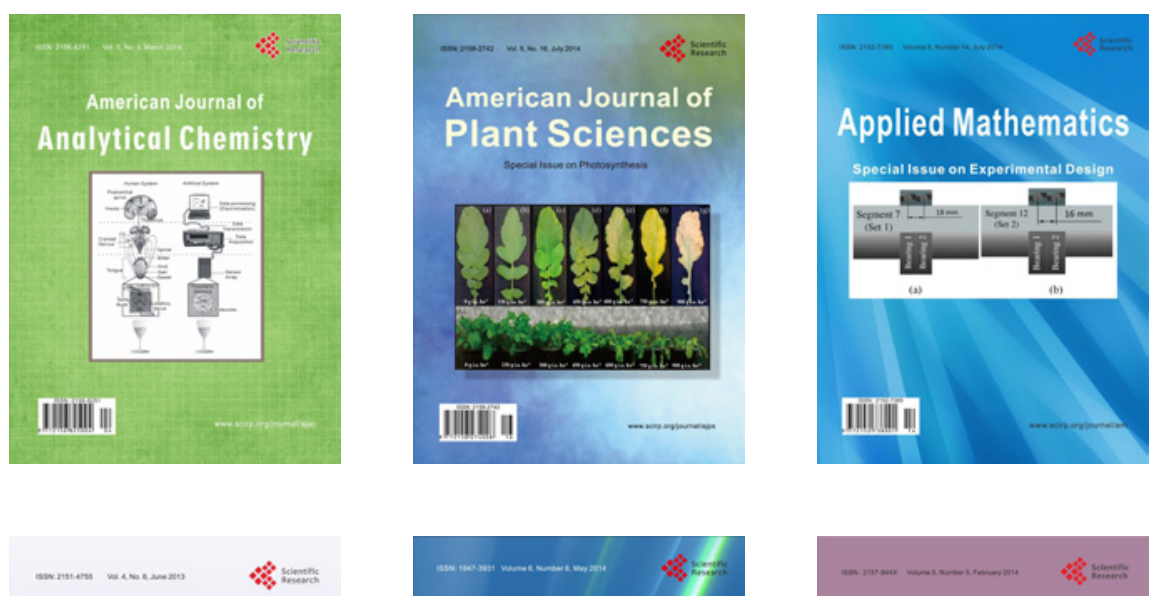

Creative Education
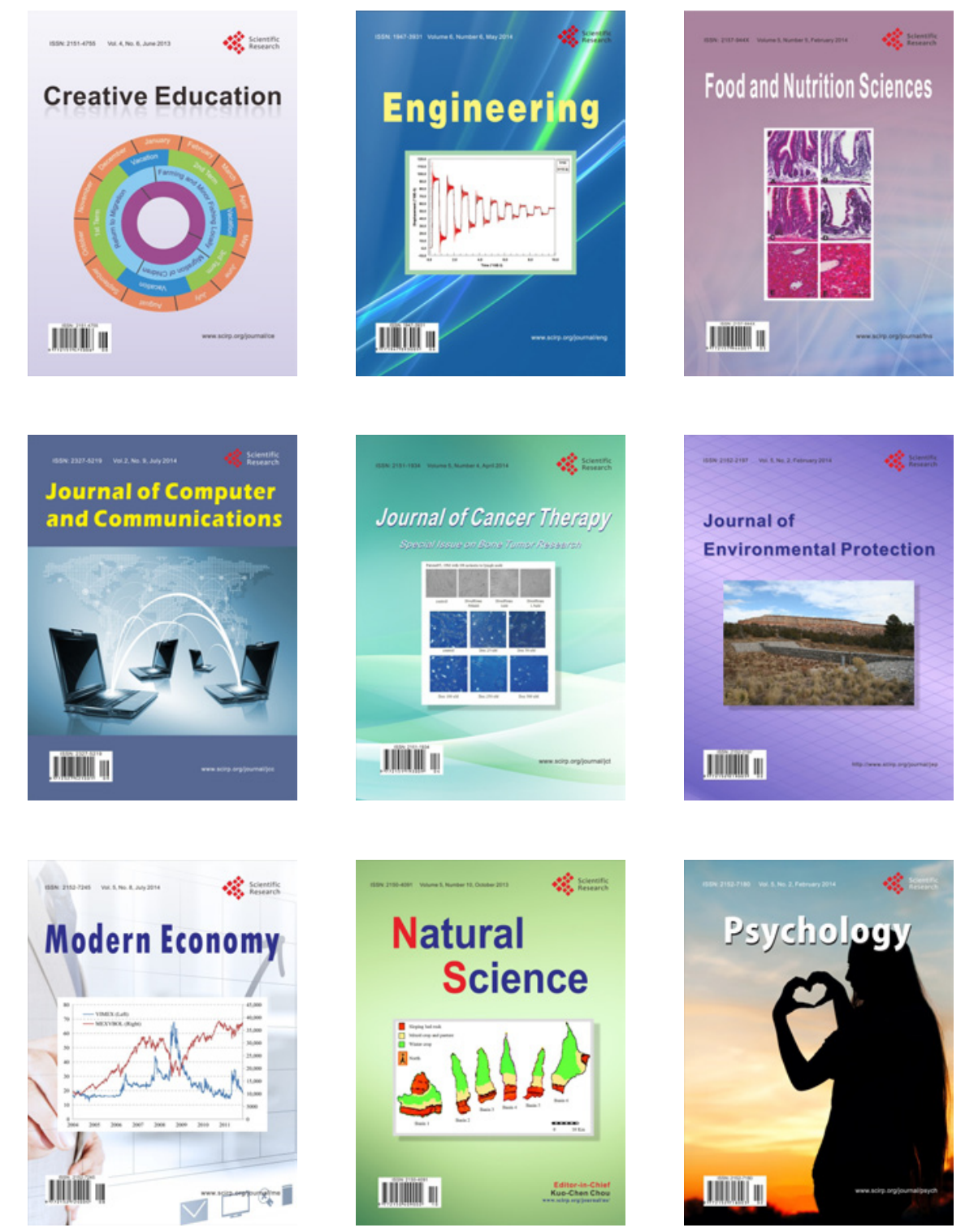